\title{
RISK AND RATIONALITY
}





\title{
RISK AND \\ RATIONALITY
}

\author{
Philosophical Foundations \\ for Populist Reforms
}

K. S. SHRADER-FRECHETTE

University of California Press

Berkeley Los Angeles Oxford 
University of California Press

Berkeley and Los Angeles, California

University of California Press, Ltd.

Oxford, England

(C) 1991 by

The Regents of the University of California

\section{Library of Congress Cataloging-in-Publication Data}

Shrader-Frechette, K. S., 1944-

Risk and rationality : philosophical foundations for populist reforms / Kristin Shrader-Frechette.

p. $\mathbf{c m}$.

Includes bibliographical references and index.

ISBN 0-520-07287-1. - ISBN 0-520-07289-8 (pbk.)

1. Risk assessment. 2. Risk-Social aspects. I. Title

T174.5.S482 1991

$363.1-\mathrm{dc} 20$

91-3294

CIP

Printed in the United States of America

$\begin{array}{llllllllll}9 & 8 & 7 & 6 & 5 & 4 & 3 & 2 & 1\end{array}$

The paper used in this publication meets the minimum requirements of American National Standard for Information Sciences-Permanence of Paper for Printed Library Materials, ANSI Z39.48-1984. (2) 
For Marie 
